\title{
Bread containing Brassica oleracea var. acephala as a source of copper and manganese
}

\section{Pão de forma contendo Brassica oleraceae var. acephala como fonte de cobre e manganês}

\author{
Érica Menezes Salvino ${ }^{1 *}$; Janeeyre Ferreira Maciel ${ }^{2}$; Roberto Kelwin Lopes da \\ Costa e Lopes ${ }^{3}$; Larissa Raphaela Gonçalves de Farias Feitosa ${ }^{4}$
}

\begin{abstract}
The aim of this study was to add dehydrated kale (Brassica oleracea var. acephala) to the formulation of a loaf of bread at concentrations of $2.5 \%$ and $5 \%$, and submit the products obtained to physico-chemical, sensory and chemical composition analysis. We also designed a control loaf of bread for comparison purposes. The addition of dehydrated kale increased the $\mathrm{pH}$ and acidity of the bread; however, it did not affect the specific volume, which ranged from 4.57 to $4.08 \mathrm{~cm}^{3} / \mathrm{g}$, and the water activity, which was 0.95 , making it possible to obtain products with satisfactory technological characteristics. In the sensory test, the kale bread showed good acceptance, with mean scores ranging from 6.5 to 8.4, and outstanding softness. The color of the bread with $5 \%$ kale was the only attribute that obtained a mean score below the one obtained for the control bread. The addition of dehydrated kale promoted greater increase in the fiber (133-281\%), calcium (176-297\%), phosphorus (201-232\%), potassium (208-318\%) and magnesium (181-300\%) content of the bread; however, only for copper (140-160\%) and manganese (76-118\%), were increments sufficient to make the products good sources of these minerals. As regards the level of oxalic acid, the concentrations obtained were far below the level considered as risky to health. Therefore, the addition of dehydrated kale to the formulation of bread resulted in products with good sensory acceptance, increased their nutritional value, and offered consumers a new choice of bread.
\end{abstract}

Key words: Sensory acceptability, kale, bakery products

\section{Resumo}

Nesse estudo o objetivo foi adicionar couve (Brassica oleraceae var. acephala) desidratada à formulação de pão de forma, nas concentrações de $2,5 \%$ e $5 \%$, e submeter os produtos obtidos as análises físico-químicas, sensoriais e de composição química. Ainda, foi elaborado um pão controle, para fins de comparação. A adição de couve desidratada promoveu elevação no $\mathrm{pH}$ e acidez dos pães, entretanto, não interferiu no volume específico, que variou de 4,57 a $4,08 \mathrm{~cm}^{3} / \mathrm{g}$, e na atividade de água, que foi de 0,95 , sendo possível obter produtos com características tecnológicas satisfatórias. No teste sensorial, os pães adicionados de couve apresentaram boa aceitação, com escores médios variando de 6,5 a 8,4, destacando-se quanto à maciez. A cor do pão com $5 \%$ de couve foi o único atributo que obteve escore médio abaixo do obtido para o pão controle. A adição de couve desidratada promoveu maior

\footnotetext{
1 Nutricionista, Dr ${ }^{\mathrm{a}}$ em Ciência e Tecnologia de Alimentos, Universidade Federal da Paraíba, UFPB, João Pessoa, PB, Brasil. E-mail: ericamsal@hotmail.com

2 Enga de Alimentos, Prof ${ }^{a}$ Dr $^{\mathrm{a}}$, Universidade Federal da Paraíba, UFPB, João Pessoa, PB, Brasil. E-mail: janeeyre@ct.ufpb.br

3 Discente em Engenharia de Alimentos, UFPB, João Pessoa, PB, Brasil. E-mail: kelwinl@hotmail.com

4 Eng ${ }^{\mathrm{a}}$ de Alimentos, M.e em Ciência e Tecnologia de Alimentos, UFPB, João Pessoa, PB, Brasil. E-mail: larissargfarias@gmail. com

* Author for correspondence
} 
elevação no teor de fibras (133-281\%), cálcio (176-297\%), fósforo (201-232\%), potássio (208-318\%) e magnésio (181-300\%) dos pães, entretanto, somente para cobre (140-160\%) e manganês (76-118\%) os incrementos foram suficientes para tornar os produtos fontes desses minerais. Quanto aos teores de ácido oxálico, as concentrações obtidas foram bem abaixo do considerado de risco a saúde. Portanto, a adição de couve desidratada à formulação de pão de forma resultou em produtos com boa aceitação sensorial, com incrementos no valor nutricional, além de oferecer ao consumidor uma nova opção de consumo desse tipo de pão.

Palavras-chave: Aceitação sensorial, couve, produtos de panificação

\section{Introduction}

Kale (Brassica oleracea var. acephala) is a source of calcium, magnesium, potassium and fiber (LISIEWSKA et al., 2009; SIKORA; BODZIARCZYK, 2012).It also contains high concentrations of ascorbic acid antioxidants (CAMPOS et al., 2009), carotenoids and chlorophyll (KORUS, 2013), substances which reduce the concentration of free radicals in the body and have been proved to prevent certain chronic degenerative diseases (LIGOR et al., 2013).

This high-water-content vegetable cannot be maintained at room temperature for more than a few days, but its life may be extended for months or even years through the application of dehydration (MWITHIGA; OLWAL, 2005), a process which promotes the concentration of nutrients and other compounds present in the kale. In this case, in addition to providing significant amounts of fiber and minerals, dehydrated kale also happens to be considered a good source of protein.

Among the dehydrated vegetables widely used by the food industry, the most common are spinach, beetroot and carrot (HAMERSKI et al., 2013), but the consumption of fresh kale still dominates at the domestic level, and it may be added in the preparation of juices (FEIBER; CAETANO, 2012), sautéed (LUCIA et al., 2011) or cooked, when used as an ingredient in elemental diets or in dishes like soups and rice (CALHEIROS; CANNIATTIBRAZACA, 2011; AYAZ et al., 2006).

Therefore, the use of dehydrated kale in the formulation of processed food constitutes an excellent alternative for increasing the consumption of this vegetable, especially by people who live in urban areas and eat out more frequently, replacing main meals with snacks (IBGE, 2011) like sandwiches (TEIXEIRA et al., 2012).

Bread has long been used for enrichment, being widely consumed by individuals from different age groups and social classes worldwide (HOBBS et al., 2014; LÓPEZ-NICOLÁS et al., 2014) and for making up for deficiencies in nutrients which are essential to health like minerals and vitamins (SABANIS et al., 2009).

In this study, the goal was to enrich loaves of bread with dried kale in concentrations which promoted improvement of their nutritional value and might result in products with good sensory acceptance.

\section{Materials and Methods}

\section{Materials}

The ingredients Dona Benta ${ }^{\mathrm{TM}}$ wheat flour, instant dry yeast, salt, sugar, Adipan dough improver (ingredients: corn starch or cassava, sugar, polysorbate 80 , calciumstearoyl-2-lactyltate, ascorbic acid and alpha-amylase enzyme) and hydrogenated vegetable fat, all used in the production of loaves, were acquired from a store in the city of João Pessoa, Brazil.

\section{Obtaining dehydrated kale}

The process of obtaining dehydrated kale consisted of the stages of selection, cleaning, bleaching and drying of kale leaves. 
Initially, the stalks were discarded and the leaves were visually evaluated; only the ones without injuries and which were uniform in color and texture were kept. Subsequently, the selected leaves were washed with tap water and immersed for 15 minutes in chlorinated water (150 ppm). Then, they were rinsed with distilled water and the excess was removed with paper towels.

The cleaned leaves were cut and subjected to bleaching, which was done by exposing the leaves to water vapor $\left(100^{\circ} \mathrm{C}\right)$ for three minutes with subsequent cooling under refrigeration at a temperature of approximately $5^{\circ} \mathrm{C}$.

The blanched leaves were kept in a drying cabin for a period of about five hours under conditions of average air velocity of $1.00 \mathrm{~m} \cdot \mathrm{s}^{-1}$ measured by an anemometer (Veloci Check, model 8330-M, São Paulo, Brazil), air temperature $55^{\circ} \mathrm{C} \pm 2^{\circ} \mathrm{C}$ and relative humidity of approximately $13 \%$, both measured with dry bulb and wet bulb thermometers (LAMBRECHT, model 761, Göttinger, Germany) attached to the top of the entrance to the drying camera. Once dry, the leaves were ground in a food processor (Magic Bullet, Model MB-1001, USA) at full speed and sifted through a mesh 60 screen to obtain a homogeneous powder. The powder obtained (moisture: 5.56\%, pH: 6.02; acidity: $4.29 \mathrm{~mL}$ of $\mathrm{NaOH}$.1N/100 mL) was vacuum packed (Selovac, 120-B, São Paulo, Brazil) in polyethylene plastic bags of low density and kept at room temperature.

\section{Preparation of breads}

\section{Formulation}

Three formulations of loaves were prepared, two with the addition of dehydrated kale, at concentrations of $2.5 \%(\mathrm{~F} 1)$ and $5.0 \%$ (F2), based on $100 \mathrm{~g}$ of flour, and one a control loaf without kale. The selection of the concentrations of kale used in this research was based on preliminary tests, and formulations at concentrations above $5 \%$ were excluded because they showed low specific volume. The basic ingredients used in the formulation of the loaves were: special wheat flour $(100 \mathrm{~g})$, water $(52 \mathrm{~g})$, instant dry yeast $(1.5 \mathrm{~g})$, salt $(1.8 \mathrm{~g})$, crystal sugar $(6.0 \mathrm{~g})$, dough improver $(1.0 \mathrm{~g})$ and hydrogenated vegetable fat $(3.0 \mathrm{~g})$.

\section{Elaboration process}

Initially, the dry ingredients along with the fat were homogenized in a blender with spirals (Steel, ST-005, São Paulo, Brazil), at slow speed for five minutes and at high speed for 10 minutes (until it reached the point of veil). During the process, chilled water at approximately $10^{\circ} \mathrm{C}$ was gradually added. Then, the $24^{\circ} \mathrm{C}$ fresh dough was kneaded, left to rest for 10 minutes and divided into $650 \mathrm{~g}$ pieces. After manual modeling, individual portions were placed in pans $(22 \mathrm{~cm} \mathrm{x} 11 \mathrm{~cm} \times 7 \mathrm{~cm})$ previously coated with hydrogenated vegetable fat and transported to the fermentation chamber (Nova Ética, series 400D, São Paulo, Brazil), and kept there for about an hour and 40 minutes at $35 \pm 1{ }^{\circ} \mathrm{C}$. After this period, the loaves were baked in a gas oven (Turbo Progás, Caxias do Sul, RS, Brazil) for 20 minutes at $200^{\circ} \mathrm{C}$. They were then cooled for three hours, sliced, packed in polyethylene bags and stored at room temperature until the time of analysis.

\section{Physico-chemical evaluation of the loaves}

Total titratable acidity (TTA) and $\mathrm{pH}$

The $\mathrm{pH}$ was determined in a previously calibrated potentiometer (Quimis, 0400, São Paulo, Brazil), and the acidity was titrated with $\mathrm{NaOH} 0.1 \mathrm{~mol} / \mathrm{L}$ to final $\mathrm{pH}$ of 8.5 expressed in $\mathrm{mL}$ of $\mathrm{NaOH} 0.1 \mathrm{~mol} / \mathrm{L}$ (ROBERT et al., 2006).

\section{Specific volume}

The volume of the loaves was determined 24 hours after processing by the seed displacement method according to the procedure described by AACC (2000), and the rapeseed was replaced by millet seed (SHITTU et al., 2008). The specific volume $\left(\mathrm{cm}^{3} / \mathrm{g}\right)$ was based on the ratio of the volume $\left(\mathrm{cm}^{3}\right)$ and the dough mass $(\mathrm{g})$. 


\section{Water activity $\left(A_{w}\right)$}

The water activity in the bread crumb was determined in Aqualab equipment (series 3, Decagon, Pullman, USA) according to the procedure described by AOAC (2000).

\section{Texture}

The texture profile of the loaves was assessed with the aid of a texturometer model TA-XT plus (Stable Micro Systems, Surrey, UK) fitted with a cylindrical probe of compression with a $35 \mathrm{~mm}$ diameter. The texture parameters determined were firmness, chewiness, springiness and cohesiveness. The instrumental analysis of the texture was conducted under the following conditions: pretest, test and post-test speed of $2.0 \mathrm{~mm} / \mathrm{s}, 5.0 \mathrm{~mm} / \mathrm{s}$ and $5.0 \mathrm{~mm} / \mathrm{s}$, respectively; with a distance of $20 \mathrm{~mm}, 20 \mathrm{~g}$ type of trigger and time between the two compressions of $5 \mathrm{sec}$. For analyzing these parameters, the ends of the loaf were removed, resulting in a cylinder approximately $6.0 \mathrm{~cm}$ long (CARR; TADINI, 2003).

\section{Sensory evaluation}

Formulations of bread containing $2.5 \%$ and $5 \%$ of kale powder were subjected to an acceptance test by 77 tasters ( $56 \%$ female and $44 \%$ male) recruited among students and staff members of the Federal University of Paraíba (UFPB). This test was performed at the Laboratory for Sensory Analysis at UFPB in individual cabins at a temperature of $22^{\circ} \mathrm{C}$ under white light, and the samples comprised a quarter of a slice of bread including crumbs and crust, obtained $24 \mathrm{~h}$ after production. The samples were served in monadic order, in disposable white plates numbered with three randomly coded digits, accompanied by mineral water.

During analysis, the tasters evaluated the color attributes of the slice of bread, aroma, crumb softness, flavor, appearance and overall acceptability using a nine-point hedonic scale $(9=$ really liked and $1=$ really disliked), according to IAL (2005). The breads were considered accepted when they obtained averages $\geq 6$ (liked slightly) (ROCHA; CARDOSO SANTIAGO, 2009). In the purchase intent test, a five-point scale $(1=$ definitely would not buy and 5 = definitely would buy) was used.

Acceptance testing was conducted after approval by the Research Ethics Committee of the Center for Health Sciences at the Federal University of Paraiba (protocol $n^{\circ}$ 0278/2013).

\section{Chemical composition of breads}

Samples of bread were evaluated for their chemical composition according to the following methodology:

- moisture, ash, proteins, according to the analytical procedures of AOAC (2000);

- total dietary fiber, according to the analytical procedures of AOAC (2005);

- lipids by the method described by Bligh and Dyer (1959);

- total and reducing sugars as described by Somogyi (1945);

- minerals by the use of atomic absorption spectrophotometry in a Varian spectrophotometer, model Spectr AA-200 VARIAN for Ca (calcium), $\mathrm{Mg}$ (magnesium), $\mathrm{Cu}$ (copper), Fe (iron), Mn(manganese) and $\mathrm{Zn}$ (zinc); by the method of flame photometry for K (potassium) (AOAC, 2005) and by the UV/vis Espectrofotometro (model Spectr AA-200 VARIAN, Mulgrave, Australia) e (QUIMIS, Q798U, São Paulo, Brazil);

- oxalic acid, by the method described by Moir (1953);

- phytic acid was determined by the colorimetric method described by Latta and Eskin (1980); 
- tannins were determined by the colorimetric method based on the reduction of the FolinDennis method, according to AOAC (2000).

Also, $\mathrm{pH}$ was determined by using a digital $\mathrm{pH}$ meter (QUIMIS, 0400, São Paulo) according to AOAC standards (2000) and acidity of the samples according to the method described by Robert et al. (2006). All analyses were performed in triplicate, with five distinct repetitions, 15 determinations of each analysis in total.

\section{Statistical analysis}

The results of physico-chemical, sensory and chemical composition analyses of sliced bread were subjected to analysis of variance (ANOVA) and Tukey's test at a significance level of 5\%. The software used was Assistat Version 7.7 Beta.

\section{Results and Discussion}

Physico-chemical evaluation of breads

Tables 1 and 2 show the results for the physicochemical analyses for the loaves of bread.

Breads with kale showed elevated $\mathrm{pH}$ and acidity compared with the control bread (Table 1), ranging from 6.22 to 6.39 and from 2.55 to $2.89 \mathrm{~mL}$ of $\mathrm{NaOH} 0.1 \mathrm{~N} / 10 \mathrm{~g}$ of bread, respectively, which was expected, especially in relation to the acidity as kale is a relatively acidic vegetable (acidity; $4.29 \mathrm{~mL}$ of NaOH0.1 N/100 mL).

For the $\mathrm{pH}$, the values observed were greater than those recommended (5.4 to 6.1) in breads (OURA et al., 1982), and for acidity they were below 3.0 $\mathrm{ml}$ of $\mathrm{NaOH} 0,1 \mathrm{~N} / 10 \mathrm{~g}$ of bread, limit commonly observed in breads added only of yeast (QUÍLEZ et al., 2006; BELZ et al., 2012).

Table 1. Values of the physico-chemical analysis of loaves.

\begin{tabular}{lccc}
\hline \multirow{2}{*}{ Parameters } & \multicolumn{3}{c}{ Formulations } \\
\cline { 2 - 4 } & CL & F1 & F2 \\
\hline $\mathrm{pH}$ & $6.22^{\mathrm{c}} \pm 0.01$ & $6.28^{\mathrm{b}} \pm 0.03$ & $6.39^{\mathrm{a}} \pm 0.01$ \\
Acidity $(\mathrm{mL}$ de $\mathrm{NaOH} 0,1 \mathrm{~N} / 10 \mathrm{~g}$ de pão) & $2.55^{\mathrm{b}} \pm 0.16$ & $2.83^{\mathrm{a}} \pm 0.75$ & $2.89^{\mathrm{a}} \pm 0.27$ \\
Specific volume $\left(\mathrm{cm}^{3} / \mathrm{g}\right)$ & $4.57^{\mathrm{a}} \pm 0.36$ & $4.51^{\mathrm{a}} \pm 0.31$ & $4.08^{\mathrm{a}} \pm 0.23$ \\
Water activity & $0.95^{\mathrm{a}} \pm 0.01$ & $0.95^{\mathrm{a}} \pm 0.00$ & $0.95^{\mathrm{a}} \pm 0.00$ \\
\hline
\end{tabular}

CL- control loaf; F1 - loaf with 2.5\% kale powder; F2 - loaf with 5\% kale powder.

Mean \pm standard deviation of triplicate analyses, with five repetitions. Means followed by the same letter do not statistically differ from each other. Tukey's test at 5\% probability level was applied.

Table 2. Texture evaluation values of loaves of bread.

\begin{tabular}{cccc}
\hline \multirow{2}{*}{ Texture Profile } & \multicolumn{3}{c}{ Formulations } \\
\cline { 2 - 4 } & CL & F1 & F2 \\
\hline Firmness $(\mathrm{N})$ & $2.93^{\mathrm{c}} \pm 0.29$ & $3.49^{\mathrm{b}} \pm 0.25$ & $4.92^{\mathrm{a}} \pm 0.07$ \\
Elasticity & $0.97^{\mathrm{a}} \pm 0.01$ & $0.97^{\mathrm{a}} \pm 0.00$ & $0.96^{\mathrm{a}} \pm 0.01$ \\
Cohesiveness & $0.71^{\mathrm{a}} \pm 0.04$ & $0.69^{\mathrm{a}} \pm 0.01$ & $0.66^{\mathrm{b}} \pm 0.01$ \\
Chewiness $(\mathrm{J})$ & $2.01^{\mathrm{b}} \pm 0.21$ & $1.96^{\mathrm{b}} \pm 0.22$ & $3.11^{\mathrm{a}} \pm 0.12$ \\
\hline
\end{tabular}

CL- control loaf; F1 - loaf with $2.5 \%$ kale powder; F2 - loaf with $5 \%$ kale powder.

Mean \pm standard deviation of triplicate analyses, with five repetitions. Means followed by the same letter do not statistically differ from each other. Tukey's test at 5\% probability level was applied. 
With respect to the specific volume, values greater than 4.0 were observed and are considered satisfactory results when compared with those (4.45 to 5.41) in other studies involving loaves of bread (OLIVEIRA et al., 2011; SILVA et al., 2009). The observed increase in the $\mathrm{pH}$ of bread with kale did not affect this characteristic, despite the growth of yeasts during fermentation being favored at $\mathrm{pH}$ around 5.0 (QUÍLEZ et al., 2006).

For water activity, values observed in the three formulations were close to those reported in the literature for a loaf of bread (LAZARIDOU; BILIADERIS, 2007).

The texture profile results are shown in Table 2. The addition of the dehydrated kale to the formulation of loaf led to an increase in firmness and chewiness, whereas cohesiveness was reduced as of 5\% concentration. Regarding elasticity, there was no significant difference between the samples $(p>0.05)$. Similar results were observed in loaves enriched with inulin and Okara flour (SILVA et al., 2009; PERESSINI; SENSIDONI, 2009). Possibly, these products promoted increase in fiber content of breads, a condition that contributed to the increase in firmness. This same effect may have been responsible for the results observed in bread with kale. According to Gandra et al. (2008) and Oliveira et al. (2007) the increase in fiber content leads to an increase in the firmness of breads.

Other factors contribute to the changes in the texture of the loaves, such as: water quantity in the dough, differences in moisture retention capacity of wheat flour, the storage time of the product, reduction in the protein content of wheat (SILVA et al., 2009; ESTELLER; LANNES, 2008) and acidity. According to Hassan et al. (2013), the decrease in $\mathrm{pH}$, associated with the increase in acidity, results in lower firmness of loaves, because of the greater activity of protease and amylase enzymes present in wheat flour. As regards chewiness and cohesiveness, no reports on the influence of acidity in these characteristics were found.

\section{Sensory evaluation}

The results of the acceptance test of both formulations of loaves with dehydrated kale and of the control bread are shown in Table 3. All samples evaluated in the sensory test were suitable for consumption according to results obtained in the microbiological analysis previously performed (BRASIL, 2001).

Table 3. Mean values and standard deviations of scores on the sensory acceptance test of loaves of bread formulations with $0 \%, 2.5 \%$ and $5 \%$ dehydrated kale.

\begin{tabular}{cccc}
\hline \multirow{2}{*}{ Attributes } & \multicolumn{3}{c}{ Formulations } \\
\cline { 2 - 4 } & CL & F1 & F2 \\
\hline Color & $7.5^{\mathrm{a}} \pm 1,35$ & $7.5^{\mathrm{a}} \pm 1.21$ & $6.5^{\mathrm{b}} \pm 1.74$ \\
Aroma & $7.1^{\mathrm{b}} \pm 1,26$ & $7.6^{\mathrm{a}} \pm 1.21$ & $7.0^{\mathrm{b}} \pm 1.49$ \\
Flavor & $7.3^{\mathrm{a}} \pm 1,19$ & $7.8^{\mathrm{a}} \pm 1.09$ & $7.1^{\mathrm{b}} \pm 1.59$ \\
Softness & $7.2^{\mathrm{b}} \pm 1,15$ & $8.4^{\mathrm{a}} \pm 0.88$ & $8.3^{\mathrm{a}} \pm 1.03$ \\
Global acceptance & $7.4^{\mathrm{ab}} \pm 1,05$ & $7.8^{\mathrm{a}} \pm 0.89$ & $7.1^{\mathrm{b}} \pm 1.26$ \\
\hline
\end{tabular}

CL- control loaf; F1 - loaf with $2.5 \%$ kale powder; F2 - loaf with $5 \%$ kale powder.

Mean \pm standard deviation of triplicate analyses, with five repetitions. Means followed by the same letter do not statistically differ from each other. Tukey's test at 5\% probability level was applied.

The three formulations tested were acceptable in terms of all sensory attributes, with mean scores ranging from 6.5 to 8.4 , values between the hedonic terms "slightly liked" and "really liked."
The loaf with dehydrated kale added in the concentration of $2.5 \%$ had a better aroma and smoothness than the control bread, not differing from the latter, however, in color and taste attributes. 
With the increase in the concentration of this ingredient to $5 \%$, there was significant reduction in the acceptance of color, and flavor and aroma showed similar acceptance to the control bread.

Loaves with kale showed a better acceptance for softness, which was not expected, given the increase in firmness and chewiness thanks to the addition of this ingredient. Further, it was found that the increase in the concentration of kale from $2.5 \%$ to $5 \%$ resulted in a decrease in acceptance for the aroma, taste and color attributes.

\section{Chemical composition of loaves}

The average moisture content of breads ranged from $34.37 \%$ to $35.57 \%$ (Table 4 ), values close to those found by Borges et al. (2012) and Oliveira et al. (2011) in traditional loaves $(35.43 \%$ and $34.85 \%$, respectively). As regards the maximum and minimum limits of desirable moisture in loaves, no reports were found in the researched literature. In Brazil, the maximum allowed was 38\%; however, the resolution that established this pattern (BRASIL, 2000) was withdrawn in 2005 (BRASIL, 2005).

The addition of dehydrated kale to the loaves promoted significant increases in fiber content, potassium, phosphorus, calcium and magnesium, $133-280 \%, \quad 208-318 \%, \quad 201-232 \%, \quad 176-297 \%$ and 181-300\%, respectively (Table 4). Despite significant increases $(p<0.05)$, the breads with cabbage could not be classified as sources of these nutrients, as they did not contain the minimum $15 \%$ of RDI established by Brazilian law for solid foods (BRASIL, 2012). In relation to calcium, the minimum amount required corresponds to $150 \mathrm{mg}$

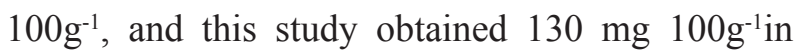
the loaf with $5 \%$ dried kale, very close to the recommended value. Therefore, the amount reached significantly contributes to the recommended daily intake of this mineral.

Table 4. Average levels of the chemical components of loaves of bread.

\begin{tabular}{|c|c|c|c|}
\hline \multirow{2}{*}{ Composition } & \multicolumn{3}{|c|}{ Formulations } \\
\hline & $\mathrm{CL}$ & F1 & F2 \\
\hline Moisture (\%) & $34.65^{b} \pm 0.49$ & $34.86^{\mathrm{ab}} \pm 1.33$ & $35.57^{\mathrm{a}} \pm 1.12$ \\
\hline 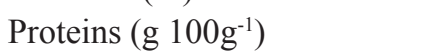 & $8.33^{b} \pm 0.05$ & $8.61^{\mathrm{a}} \pm 0.08$ & $8.66^{\mathrm{a}} \pm 0.03$ \\
\hline Lipids $\left(g 100 g^{-1}\right)$ & $3.72^{\mathrm{a}} \pm 0.21$ & $3.30^{\mathrm{b}} \pm 0.09$ & $3.22^{\mathrm{b}} \pm 0.05$ \\
\hline Ashes (g 100 g $\left.{ }^{-1}\right)$ & $1.64^{\mathrm{c}} \pm 0.05$ & $1.77^{\mathrm{b}} \pm 0.03$ & $1.93^{\mathrm{a}} \pm 0.04$ \\
\hline $\operatorname{Starch}\left(\mathrm{g} 100 \mathrm{~g}^{-1}\right)$ & $39.75^{\mathrm{a}} \pm 0.41$ & $37.68^{\mathrm{b}} \pm 0.52$ & $36.75^{b} \pm 0.62$ \\
\hline Dietary fiber $\left(\mathrm{g} 100 \mathrm{~g}^{-1}\right)$ & $0.52^{\mathrm{c}} \pm 0.05$ & $1.21^{\mathrm{b}} \pm 0.04$ & $1.98^{\mathrm{a}} \pm 0.04$ \\
\hline Calcium (mg 100g $\left.\mathrm{g}^{-1}\right)$ & $32.81^{\mathrm{c}} \pm 0.43$ & $90.61^{\mathrm{b}} \pm 0.06$ & $130.34^{\mathrm{a}} \pm 0.05$ \\
\hline Phosphorus (mg 100g $\mathrm{g}^{-1}$ ) & $27.57^{\mathfrak{c}} \pm 0.41$ & $83.00^{\mathrm{b}} \pm 0.15$ & $91.63^{\mathrm{a}} \pm 0.21$ \\
\hline Potassium (mg 100g-1) & $35.43^{\mathrm{c}} \pm 0.27$ & $108.98^{\mathrm{b}} \pm 0.09$ & $148.11^{a} \pm 0.19$ \\
\hline Magnesium (mg 100g $\left.\mathrm{g}^{-1}\right)$ & $8.43^{\mathrm{c}} \pm 0.11$ & $23.74^{\mathrm{b}} \pm 0.06$ & $33.75^{\mathrm{a}} \pm 0.08$ \\
\hline Iron $\left(\mathrm{mg} 100 \mathrm{~g}^{-1}\right)$ & $2.23^{\mathrm{c}} \pm 0.01$ & $2.95^{\mathrm{b}} \pm 0.01$ & $3.48^{\mathrm{a}} \pm 0.01$ \\
\hline Zinc $\left(\operatorname{mg~} 100 \mathrm{~g}^{-1}\right)$ & $0.56^{\mathrm{c}} \pm 0.01$ & $0.72^{\mathrm{b}} \pm 0.01$ & $0.86^{\mathrm{a}} \pm 0.01$ \\
\hline Manganese (mg 100g $\left.\mathrm{g}^{-1}\right)$ & $0.17^{\mathrm{c}} \pm 0.02$ & $0.30^{\mathrm{b}} \pm 0.01$ & $0.37^{\mathrm{a}} \pm 0.00$ \\
\hline Copper (mg 100 $\left.\mathrm{g}^{-1}\right)$ & $0.05^{\mathrm{c}} \pm 0.01$ & $0.12^{\mathrm{b}} \pm 0.01$ & $0.13^{\mathrm{a}} \pm 0.00$ \\
\hline Total oxalic acid $\left(\mathrm{mg} 100 \mathrm{~g}^{-1}\right)$ & $0.05^{\mathrm{c}} \pm 0.13$ & $0.38^{\mathrm{b}} \pm 0.12$ & $0,51^{\mathrm{a}} \pm 0.21$ \\
\hline Phytic acid (mg 100g $\left.{ }^{-1}\right)$ & $0.04^{\mathrm{c}} \pm 0.02$ & $0.12^{b} \pm 0.04$ & $0.34^{\mathrm{a}} \pm 0.01$ \\
\hline Tannins (mg $\left.100 \mathrm{~g}^{-1}\right)$ & $0.09^{c} \pm 0.00$ & $0.41^{b} \pm 0.03$ & $0.63^{\mathrm{a}} \pm 0.03$ \\
\hline
\end{tabular}

CL- control loaf; F1 - loaf with $2.5 \%$ kale powder; F2 - loaf with $5 \%$ kale powder.

Mean \pm standard deviation of triplicate analyses, with five repetitions. Means followed by the same letter do not statistically differ from each other. Tukey's test at 5\% probability level was applied. 
For copper and manganese, the observed increases were sufficient to classify the loaf containing $2.5 \%$ dried kale as a source of manganese and the loaf with $5 \%$ as a source of manganese and copper. Copper is an important cofactor of enzymes involved in iron metabolism and may prevent hematologic abnormalities including anemia (GRIFFITH et al., 2009), amino acid metabolism, cholesterol and carbohydrates (MERDIVAN et al., 2004).

As regards iron and proteins, the quantities present in the control bread already met the standards required by legislation to classify the bread as a source of these nutrients. Considering that adding kale promoted increases in these nutrients, the two formulations which received this ingredient can also be classified as sources of iron and protein (BRASIL, 2012).

The addition of the dehydrated kale to loaves of bread also increased the concentration of factors that affect the bioavailability of nutrients. For oxalic acid, the amount obtained (Table 4) was far below the threshold considered a risk to health $\left(2 \mathrm{~g} \mathrm{~kg}^{-}\right.$ 'body weight) (SAVAGE, 2000), and for phytic acid and tannins no reports were found in the literature.

\section{Conclusion}

The addition of dehydrated kale in the formulation of loaves of bread contributed to the improvement of their nutritional value, promoting a significant increase in levels of fiber and minerals; they were notable for being a source of copper and manganese. The loaves constitute an excellent alternative for stimulating the consumption of this vegetable, especially by people in the habit of replacing main meals with snacks.

\section{References}

AMERICAN ASSOCIATION OF CEREAL CHEMISTS - AACC. Approved methods of the AACC. $8^{\text {th }}$ ed. St. Paul: Editora AACC, 2000.
ASSOCIATION OF OFFICIAL ANALYTICAL CHEMISTS - AOAC. Official methods of analysis of the Association of Official Analytical Chemists. $17^{\text {th }} \mathrm{ed}$. Washington: AOAC, 2000.

Official methods of analysis of the Association of Official Analytical Chemists. Washington: AOAC, 2005. $1018 \mathrm{p}$.

AYAZ, F. A.; GLEW, R. H.; MILLSON, M.; HUANG, H. S.; CHUANG, L. T.; SANZ, C.; HAYIRLIOGLUAYAZ, S. Nutrient contents of kale (Brassica oleraceae L. var. acephala DC.). Food Chemistry, v. 96, n. 4, p. 572-579, 2006.

BELZ, M. C. E.; MAIRINGER, R.; ZANNINI, E.; RYAN, L. A. M.; CASHMAN, K. D.; ARENDT E. K. The effect of sourdough and calcium propionate on the microbial shelf-life of salt reduced bread. Applied Microbial and Cell Physiology, v. 96, n. 2, p.493-501, 2012.

BLIGH, E. G.; DYER, W. J. A rapid method of total lipid extraction and purification. Canadian Journal of Biochemistry and Physiology, Ottawa, v. 37, n. 8, p. 911917, 1959.

BORGES, J. T. S.; PAULA, C. D.; PIROZI, M. R.; OLIVEIRA, K. Qualidade nutricional de pão de forma enriquecido com farinha de quinoa. Revista Alimentos Hoy, v. 21, n. 27, p. 55-67, 2012.

BRASIL. Agência Nacional de Vigilância Sanitária ANVISA. Agência Portaria RDC n ${ }^{\circ} 90$, de 18 de outubro de 2000. Regulamento técnico para fixação de identidade e qualidade do pão. Diário Oficial [da] República Federativa do Brasil, Brasília, 18 out. 2000. Seção 1, p. 1-7.

Agência Nacional de Vigilância Sanitária - ANVISA. Regulamento técnico sobre padrões microbiológicos para alimentos. Resolução-RDC n ${ }^{\circ} 12$, de 2 de janeiro de 2001. Diário Oficial [da] República Federativa do Brasil, Brasília, 10 jan. 2001. Seção 1, p. 46-53.

- Ministério da Saúde. Agência Nacional de Vigilância Sanitária (ANVISA) Resolução RDC n²63 DE 22 de setembro de 2005. Dispões sobre o Regulamento Técnico para produtos de cereais, amidos, farinhas e farelos. Diário Oficial [da] República Federativa do Brasil, Brasília, 23 set. 2005. Seção 1, p. 268-269.

Ministério da Saúde/Agência Nacional de Vigilância Sanitária. Resolução ${ }^{\circ} 54$, de 12 de novembro de 2012. Regulamento técnico sobre informação nutricional complementar. Diário Oficial [da] União, Brasília, 12 nov. 2012. Seção 1, p. 15. 
CALHEIROS, K. O.; CANNIATTI-BRAZACA, S. G. Disponibilidade de ferro, digestibilidade de proteína e teor de $\beta$-caroteno em formulados alternativos de baixo custo para alimentação enteral de idosos. Ciência e Tecnologia de Alimentos, Campinas, v. 31, n. 1, p. 41-55, 2011.

CAMPOS, F. M.; RIBEIRO, S. M. R.; LUCIA, C. M. D.; PINHEIRO-SANT'ANA, H. M. Optimization of methodology to analyze ascorbic and dehydroascorbic acid in vegetables, Química Nova, São Paulo, v. 32, n. 1, p. 87-91, 2009.

CARR, L. G.; TADINI, C. C. Influence of yeast and vegetable shortening on physical and texture parameters of frozen part baked French bread. Lebensmittel Wissenschaft und - Technologie, v. 36, n. 6, p. 609-614, 2003.

ESTELLER, M. S.; LANNES, S. C. S. Production and characterization bread using scaldedrye. Journal of Texture Studies, Trumbull, v. 39, n. 1, p. 56-67, 2008.

FEIBER, L. T.; CAETANO, R. Estudo da composição centesimal e teores de cálcio em polpas de couve (Brassica oleracea var. acephala). Alimentos e Nutrição, Araraquara, v. 23, n. 1, p. 141-145, 2012.

GANDRA, K. M.; DEL BIANCHI, M.; GODOY, V. P.; QUEIROZ, F. P. C.; JOY, S. C. Aplicação de lipase e monoglicerídeo em pão de forma enriquecido com fibras. Ciência e Tecnologia de Alimentos, Campinas, v. 28, n. 1, p. 182-192, 2008.

GRIFFITH, D. P.; LIFF, D. A.; ZIEGLER, T. R.; ESPER, G. J.; WINTON, E. F. Acquired copper deficiency: a potentially serious and preventable complication following gastric bypass surgery. Obesity, v. 17, n. 4, p. 827-831, 2009.

HAMERSKI, L.; REZENDE, M. J. C.; SILVA, B. V. Usando as cores da natureza para atender aos desejos do consumidor: substâncias naturais como corantes na indústria alimentícia. Revista Virtual de Química, v. 5, n. 3, p. 394-420, 2013.

HASSAN, A. A.; EL-SHAZLY, H. A. M.; SAKR, A. M.; RAGAB, W. A. Influence of substituting water with fermented skim milk, acid cheese whey or buttermilk on dough properties and baking quality of pan bread. World Journal of Dairy \& Food Sciences, v. 8, n. 1, p. 100-117, 2013.

HOBBS, D. A.; ASHOURI, A.; GEORGE, T. W.; LOVEGROVE, J. A.; METHVEN, L. The consumer acceptance of novel vegetable-enriched bread products as a potential vehicle to increase vegetable consumption. Food Research International, Barking, v. 58, n. 1, p. 1522, 2014.
INSTITUTO BRASILEIRO DE GEOGRAFIA E ESTATÍSTICA - IBGE. Pesquisa de orçamentos familiares 2008-2009: avaliação nutricional da disponibilidade domiciliar de alimentos no Brasil. Rio de Janeiro: IBGE, 2011. 150 p.

KORUS, A. Effect of preliminary and technological treatments on the content of chlorophylls and carotenoids in kale (brassica oleracea 1. var. acephala). Journal of Food Processing and Preservation, v. 37, n. 4, p. 335344, 2013.

LATTA, M.; ESKIN, M. A simple and rapid colorimetric method for phytate determination. Journal of Agricultural and Food Chemistry, Washington, v. 28, n. 6, p. 13131315,1980 .

LAZARIDOU, A.; BILIADERIS, C. G. Molecular aspects of cereal b-blucan functionality: physical properties, technological applications and physiological effects. Journal of Cereal Science, London, v. 46, n. 2, p. 101-118, 2007.

LIGOR, M.; TRZISZKA, T.; BUSZEWSKI, B. Study of antioxidant activity of biologically active compounds isolated from green vegetables by coupled analytical techniques. Food Analytical Methods, v. 6, n. 2, p. 630636, 2013.

LISIEWSKA, Z.; GEBCZYNSKI, P.; BERNAS, E.; KMIECIK, W. Retention of mineral constituents in frozen leafy vegetables prepared for consumption. Journal Food Composition and Analysis, v. 22, n. 3, p. 218-223, 2009.

LÓPEZ-NICOLÁS， R.; FRONTELA-SASETA， C.; GONZÁLEZ-ABELLÁN, R.; BARADO-PIQUERAS, A.; PEREZ-CONESA, D.; ROS-BERRUEZO, G. Folate fortification of white and whole-grain bread by adding Swiss chard and spinach. Acceptability by consumers. Food Science and Technology, London, v. 59, n. 1, p. 263-269, 2014.

LUCIA, C. M. D.; SILVA, E. R.; RIBEIRO, S. M. R.; PINHEIRO-SANT'ANA, H. M. Otimização de método para análise de folatos em hortaliças folhosas por cromatografia líquida de alta eficiência com detecção por fluorescência. Química Nova, São Paulo, v. 34, n. 2, p. 335-340, 2011.

MERDIVAN, M.; YILMAZA, E.; HAMAMCIA, C.; AYGUNC, R. S. Basic nutrients and element contents of white cheese of diyarbakır in turkey. Food Chemistry, Reading, v. 87, n. 2, p. 163-171, 2004.

MOIR, K. W. Determination of oxalic acid in plant Queensland. Journal Agricultural Science, v. 10, n. 1, p. 1-3, 1953. 
MWITHIGA, G.; OLWAL, J. O. The drying kinetics of kale (Brassica oleraceae) in a convective hot air dryer. Journal of Food Engineering, Essex, v. 71, n. 4, p. 373378, 2005.

OLIVEIRA, N. M. A. L.; MACIEL, J. F.; LIMA, A. S.; SALVINO, E. M.; MACIEL, C. E. P.; OLIVEIRA, D. P. M. N.; FARIAS, L. R. G. Características físicoquímicas e sensoriais de pão de forma enriquecido com concentrado protéico de soro de leite e carbonato de cálcio. Revista Instituto Adolfo Lutz, São Paulo, v. 70, n. 1, p. 16-22, 2011.

OLIVEIRA, T. M.; PIROZI, M. R.; BORGES, J. T. S. Elaboração de pão de sal utilizando farinha mista de trigo e linhaça. Alimentos e Nutrição, Araraquara, v. 18, n. 2, p. 141-150, 2007.

OURA, E.; SOUMALAINEN, H.; VISKARI, R. Breadmaking. Economyc Microbiology, v. 7, n. 1, p. 87146, 1982.

PERESSINI, D.; SENSIDONI, A. Effect of soluble dietary fibre addition on rheological and breadmaking properties of wheat doughs. Journal of Cereal Science, London, v. 49, n. 2, p. 190-201, 2009.

QUÍLEZ, J.; RUIZ, J. A.; ROMERO, M. P. Relationships between sensory flavor evaluation and volatile and nonvolatile compounds in commercial wheat bread type baguette. Journal Food Science, v. 71, n. 6, p. 423-427, 2006.

RANGANNA, S. Manual of analysis of fruit and vegetable products. New Delhi: Tata Mcgraw-Hill, 1979. $1112 \mathrm{p}$.

ROBERT, H.; GABRIEL, V.; LEFEBVRE, D.; RABIER, P.; VAYSSIER, Y.; FONTAGNÉ-FAUCHER, C. Study of the Lactobacillus plantarum and Leuconostoc starters during a complete wheat sourdough breadmaking process. Food Science and Technology, London, v. 39, n. 3, p. 256-265, 2006.
ROCHA, L. S.; CARDOSO SANTIAGO, R. A. Implicações nutricionais e sensoriais da polpa e casca de baru (Dipterix Alata vog.) na elaboração de pães. Ciência e Tecnologia de Alimentos, Campinas, v. 29, n. 4, p. 820$825,2009$.

SABANIS, D.; LEBESI, D.; TZIA, C. Effect of dietary fibre enrichment on selected properties of gluten-free bread. Food Science and Technology, London, v. 42, n. 8, p. 1380-1389, 2009.

SAVAGE, G. P.; VANHANEN, L.; MASON, S. M.; ROSS, A. B. Effect of cooking on the soluble and insoluble oxalic acid content of some New Zealand foods. Journal Food Composition and Analysis, v. 13, n. 3, p. 201-206, 2000.

SHITTU, T. A.; DIXON, A.; AWONORIN, S. O.; SANNI, L. O.; MAZIYA-DIXON, B. Bread from composite cassava-wheat flour. II: Effect of cassava genotype and nitrogen fertilizer on bread quality. Food Research International, Barking, v. 41, n. 6, p. 569-578, 2008.

SIKORA, E.; BODZIARCZYK, I. Composition and antioxidant activity of kale (Brassica oleracea L. var. acephala) raw and cooked. Acta Scientiarum Polonorum, v. 11, n. 3, p. 239-248, 2012.

SILVA, L. H.; PAUCAR-MENACHO, L. M.; VICENTE, C. A.; SALLES, A. S.; STEEL, C. J. Desenvolvimento de pão de fôrma com a adição de farinha de "okara". Brazilian Journal of Food Technology, Campinas, v. 12, n. 4, p. 315-322, 2009.

SOMOGYI, M. A. New reagent for determination of sugars. The Journal of Biological Chemistry, Maryland, v. 160, n. 1, p. 61-68, 1945.

TEIXEIRA, A. S.; PHILIPPI, S. T.; LEAL, G. V. S.; ARAKI, E. L.; ESTIMA, C. C. P.; GUERREIRO, R. E. R. Substituição de refeições por lanches em adolescentes. Revista Paulista de Pediatria, São Paulo, v. 30, n. 3, p. 330-337, 2012. 